\title{
Childhood Medulloblastoma
}

National Cancer Institute

\section{Source}

National Cancer Institute. Childhood Medulloblastoma. NCI Thesaurus. Code C3997.

A medulloblastoma occurring in children. 